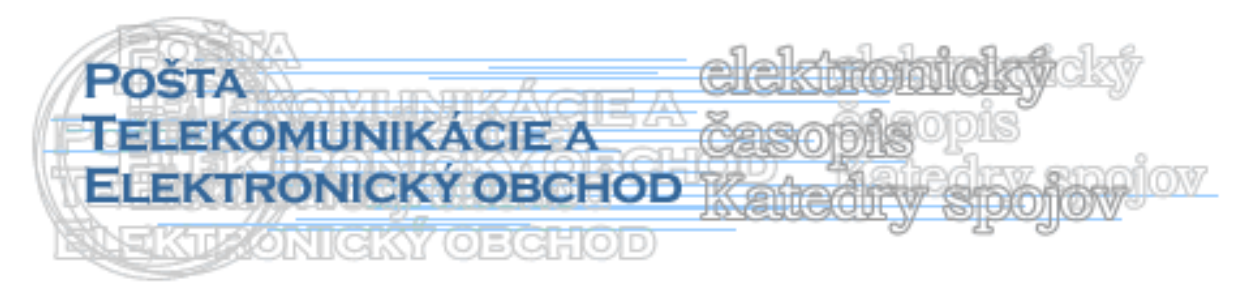

\title{
PRÍSTUPY K TVORBE OPTIMÁLNEHO PORTFÓLIA
}

\section{Lucia Tokarčíková ${ }^{+}$}

Každý investor pri napín̆aní svojho základného ciel'a, zhodnocovania svojich vložených prostriedkov, stojí pred problémom maximalizácie návratnosti z investície, pričom musí rešpektovat' rizikový faktor spojený s investovaním. Úlohou investora je zostavit' portfólio z dostupných aktív, ktoré bude napínat' jeho individuálne potreby. Proces tvorby takého portfólia možno zhrnút' do troch základných krokov:

na začiatku musí investor zhromaždit' potrebné vstupné údaje o kurzoch akcií a ich rozličných štatistických ukazovatel'och, ktoré charakterizujú správanie sa jednotlivých akcií v čase;

$>$ d’alším krokom je zostavenie portfólia z vybraných akcií, ktoré bude tvorené rôznymi kombináciami podielov kapitálu, vložených do jednotlivých akcií. Pre investora budú zaujímavé tie portfóliá, ktoré ležia na efektívnej hranici, teda portfólia, ktoré ležia na efektívnej hranici, danom očakávanom výnose minimálne riziko. Do tejto fázy vstupuje faktor diverzifikácie, ktorá umožňuje obmedzit' riziko spojené s investíciou. Diverzifikácia je typická pridávaním akcií do portfólia, za účelom zníženia rizika;

v poslednom kroku si investor na základe osobných preferencií vyberá svoje optimálne portfólio. Existuje niekol'ko metód výberu optimálneho portfólia, pričom výber konkrétnej metódy závisí od rôznych okolností, napr. z časového hl'adiska, teda či ide o investora, ktorý investuje dlhodobo alebo krátkodobo, alebo od vzt'ahu investora $\mathrm{k}$ riziku.

Ciel'om článku je informovat' o spôsoboch, ktoré môže prijat' investor pri výbere optimálneho portfólia.

V prípade klasického Markowitzovho prístupu si investor po vyselektovaní určitej skupiny akcií, ktoré budú tvorit' jeho portfólio, stanoví časové obdobie z minulosti, z ktorého bude čerpat' informácie o vývoji kurzu akcií. Investor sa taktiež rozhodne, či do analýzy zahrnie denné, týždenné alebo mesačné kurzy akcií. Následne sa vyčíslia miery výnosu každej akcie pre každé dve po sebe nasledujúce obdobia. Okrem toho možno vyjadrit' výkonnost' jednotlivých akcií, ktorá prestavuje pomer kurzu akcie v jednotlivých obdobiach a kurzu akcie na začiatku sledovaného obdobia. Na základe toho môže investor vyvodit' určité závery o jednotlivých akciách, napr. o tom, či kurz akcie počas sledovaného obdobia rástol, klesal alebo bol na rovnakej úrovni a taktiež aká bola výška výnosov v jednotlivých obdobiach.

\footnotetext{
+ Ing. Lucia Tokarčíková, externá doktorandka na Katedre spojov, Fakulta prevádzky a ekonomiky dopravy a spojov, Žilinská univerzita v Žiline, Univerzitná 1, 01026 Žilina, Slovenská republika
} 
Z údajov výnosov je potrebné vyčíslit’ základné štatistické ukazovatele, ktoré budú vstupnými premennými pre výpočet očakávaného výnosu a rizika portfólia. Pri Markowitzovom prístupe sú týmito vstupmi aritmetické priemery výnosov jednotlivých akcií, rozptyl výnosov, resp. štandardná odchýlka výnosov jednotlivých akcií a kovariančná matica. Rozptyl vyjadruje v akom rozmedzí sa pohybujú výnosy akcií počas sledovaného obdobia, pričom štandardná odchýlka je odmocninou rozptylu a vyjadruje rizikovost' akcií. Kovariančná matica je maticou, ktorej hlavná diagonála je tvorená rozptylom jednotlivých akcií a ostatné polia vyjadrujú závislosti pohybu výnosov jednej akcie od pohybu výnosov druhej akcie. V tejto fáze si môže investor zostavit' aj korelačnú maticu, ktorá vyjadruje, aká forma závislosti existuje medzi výnosmi dvoch akcií.

Zo získaných vstupov je možné vyjadrit' očakávaný výnos a riziko portfólia. Za účelom nájdenia efektívnej hranice portfólií je potrebné nájst' optimálne zloženie portfólia, reprezentované podielom, v ktorom je vložený kapitál rozdelený medzi jednotlivé aktíva. Optimálnemu zloženiu portfólia bude zodpovedat' taký podiel, pri ktorom je očakávaný výnos pri danej úrovni rizika najväčší, resp. pri ktorom je riziko pri danom očakávanom výnose najmenšie. $Z$ tejto efektívnej hranice si investor vyberá svoje optimálne portfólio v závislosti od svojho postoja k riziku. Na tomto mieste je potrebné poznamenat', že Markowitzov prístup $\mathrm{k}$ výberu portfólia je vhodný pre investorov, ktorých ciel'om je optimalizácia portfólia pre jedno nasledujúce obdobie. Je nutné zdôraznit', že Markowitzov prístup nie je univerzálnym prístupom a za istých okolností alebo v závislosti od mentality investora je vhodné použit' iný prístup.

Pojem optimálne portfólio vznikne ako kombinácia trhového portfólia a bezrizikového aktíva $^{1}$. Presná kombinácia trhového portfólia a bezrizikového aktíva závisí na stupni averzie k riziku. Každý investor sa musí rozhodnút', aké riziko je preňho prijatel'né a potom na základe tohto rozhodnutia vytvorit' portfólio. Investor si vyberie svoje vlastné optimálne portfólio na základe subjektívneho prístupu k riziku.

Postup, ktorý vedie $\mathrm{k}$ určeniu optimálneho portfólia rizikových cenných papierov navrhli Elton a Gruber. Na základe nimi navrhnutého postupu možno odvodit' a dokázat' pravidlá výberu tohto portfólia. Hovoria, že existuje jednoznačné číslo, ktoré meria vhodnost' zaradenia cenného papiera do optimálneho portfólia. Manažér odhaduje očakávané výnosy a koeficienty beta rôznych cenných papierov a tým môže ohodnotit' všetky cenné papiere k mimoriadnemu výnosu vzhl’adom na „,k - beta“. Formálne to možno zapísat’ ako:

$$
\text { Mimoriadny výnos k beta }=\frac{\overline{\boldsymbol{r}_{\boldsymbol{i}}}-\boldsymbol{r}_{\boldsymbol{f}}}{\boldsymbol{\beta}_{\boldsymbol{i}}}
$$

kde

$\overline{\mathrm{r}}_{\mathrm{i}}$ - očakávaný výnos cenného papiera $\mathrm{i}$

$\mathrm{r}_{\mathrm{f}}$ - bezriziková sadzba

$\beta_{\mathrm{i}}$ - citlivost' i-tého cenného papiera vzhl'adom na niektorý ukazovatel' trhu.

\footnotetext{
${ }^{1}$ Bezrizikové aktívum predstavuje aktívum, ktorého výnosnost' je istá už na začiatku doby držby v portfóliu. Ked' investor nakúpi toto aktívum na začiatku doby investovania, bude presne vidiet' akú hodnotu bude aktívum mat' na konci doby investovania. Pretože o konečnej hodnote bezrizikového aktíva nie je žiadna pochybnost', smerodajná odchýlka bezrizikového aktíva je definovaná ako nula.
} 
Podiel vo vzt'ahu meria dodatočný výnos cenného papiera na jednotku nediverzifikovatel'ného rizika. Čím je vyšší mimoriadny výnos „k - beta“, tým atraktívnejší je cenný papier pre konštrukciu optimálneho portfólia. Počet cenných papierov v optimálnom portfóliu bude závisiet' na jednoznačnom hraničnom pomere $C^{*}$ (bod rezu) pre mimoriadny výnos $\mathrm{k}$ beta taký, že všetky cenné papiere s mimoriadnym výnosom $\mathrm{k}$ beta vyšším ako tento pomer, budú zahrnuté do portfólia a výpočtu $\mathrm{C}^{*}$, zatial' čo všetky cenné papiere $\mathrm{s}$ mimoriadnym výnosom $\mathrm{k}$ beta nižším ako daný pomer, nebudú zahrnuté do optimálneho portfólia a ani do výpočtu $\mathrm{C}^{*}$.

Hraničný pomer $\mathrm{c}_{\mathrm{i}}$ portfólia obsahujúceho $\mathrm{N}$ cenných papierov možno zapísat’ ako :

$$
c_{i}=\frac{\sigma_{m}^{2} \sum_{i=1}^{N} \frac{\left(\bar{r}_{i}-r_{f}\right) \beta_{i}}{\sigma_{e i}^{2}}}{1+\sigma_{m}^{2} \sum_{i=1}^{N}\left(\frac{\beta_{i}^{2}}{\sigma_{e i}^{2}}\right)}
$$

kde $\sigma_{\mathrm{m}}{ }^{2}$ je rozptyl trhového portfólia a $\sigma_{\mathrm{ei}}{ }^{2}$ je nesystematické riziko i-tého cenného papiera. Hodnotu $\mathrm{C}^{*}$ vypočítame $\mathrm{z}$ charakteristík všetkých cenných papierov, ktoré patria do optimálneho portfólia.

Do portfólia zarad'ujeme cenné papiere, ak platí:

$$
\frac{\overline{\boldsymbol{r}}_{\boldsymbol{i}}-\boldsymbol{r}_{f}}{\beta_{i}}>c_{i}
$$

Po nájdení všetkých $\mathrm{c}_{\mathrm{i}}$ určíme hraničný pomer $\mathrm{C}^{*}$. Bude to také $\mathrm{c}_{\mathrm{i}}$, pre ktoré platí, že všetky cenné papiere vo výpočtoch majú mimoriadny výnos $\mathrm{k}$ beta pod jeho hodnotu. Všetky cenné papiere $\mathrm{s}$ mimoriadnym výnosom $\mathrm{k}$ beta nad túto úroveň implementujeme do optimálneho portfólia. Váhové zastúpenie cenného papiera v portfóliu je dané vzt’ahom:

$$
x_{i}=\frac{\varpi_{i}}{\sum_{i=1}^{N} \varpi_{i}}
$$

kde

$$
\varpi_{i}=\frac{\beta_{i}}{\sigma_{e i}}\left(\frac{\overline{\boldsymbol{r}}_{i}-\boldsymbol{r}_{f}}{\beta_{i}}-C^{*}\right)
$$


Tento podiel rastie s rastom k podielu beta a klesá s rastom systematického aj nesystematického rizika.

\section{Pri hl'adaní optimálneho portfólia môžu nastat' tieto prípady:}

a) Krátky predaj (Sell short) je povolený a bezrizikové vypožičiavanie a investovanie je možné;

b) Krátky predaj je povolený, bezrizikové vypožičiavanie a investovanie je zakázané;

c) Krátky predaj je zakázaný, ale bezrizikové vypožičiavanie a investovanie je povolené;

d) Krátky predaj a bezrizikové vypožičiavanie a investovanie sú zakázané.

\section{Variantné prístupy k tvorbe optimálneho portfólia:}

\section{* „Kritérium maximalizácie geometrického priemeru výnosov“}

Jedným z variantných prístupov k optimalizácii portfólia je prístup, pri ktorom si investor vyberá portfólio, ktoré maximalizuje geometrický priemer výnosov. Postup pri konštrukcii takého portfólia je do určitej miery podobný ako Markowitzov prístup, s tým rozdielom, že vstupmi do analýzy nie sú aritmetické priemery výnosov jednotlivých akcií, alebo geometrické priemery, resp. z nich odvodené pseudo-aritmetické priemery výnosov jednotlivých akcií.

Stanovenie očakávaného výnosu portfólia podl’a kritéria maximalizácie geometrického priemeru je možné realizovat' štyrmi spôsobmi, reprezentované štyrmi formulkami, pričom dve z nich využívajú aritmetické priemery výnosov jednotlivých akcií na stanovenie geometrického priemeru výnosov portfólia a zvyšné dve využívajú geometrický priemer výnosov akcií na výpočet geometrického priemeru výnosov portfólia.

Podobne ako pri Markowitzovom prístupe, aj pri tomto variantnom prístupe sa hl'adajú optimálne váhy akcií, resp. podiel kapitálu vloženého do jednotlivých akcií.

Poloha a tvar efektívnej hranice $\mathrm{v}$ tomto prípade sa ale líšia od Markowitzovej efektívnej hranice. Hranica portfólií, ktoré maximalizujú geometrický priemer výnosov má po istú úroveň rizika stúpajúcu tendenciu, následne ale začína klesat'. Čast' hranice portfólií, ktoré maximalizujú geometrický priemer výnosov, začínajú od bodu kedy začína krivka klesat', nebude efektívnou hranicou, pretože namiesto portfólia $\mathrm{z}$ tejto hranice s určitým očakávaným výnosom a úrovňou rizika možno vybrat' portfólio s rovnakým očakávaným výnosom ale nižšou úrovňou rizika. Efektívnou hranicou v tomto prípade bude len tá čast' krivky, ktorá má rastúcu tendenciu a končí bodom kedy začína klesat'.

$\mathrm{Na}$ rozdiel od Markowitzovho prístupu, alternatívny prístup, pri ktorom sa maximalizuje geometrický priemer výnosov, je vhodné použit', ak zámerom investora je dlhodobá optimalizácia portfólia, teda optimalizácia portfólia na niekol'ko budúcich období. Okrem toho je vhodné spomenút', že pri skúmaní vlastností optimálnych portfólií, ktoré maximalizujú geometrický priemer výnosov sa zistilo, že maximalizácia geometrického priemeru výnosov je ekvivalentná maximalizácií očakávanej hodnoty logaritmickej úžitkovej funkcie investora. Pritom z dlhodobého hl'adiska je takmer isté, že portfólio, ktoré sa riadi podl'a logaritmickej úžitkovej funkcie bude mat' vyššiu hodnotu ako portfólio, riadené l'ubovol'nou inou stratégiou. $Z$ tohto pohl'adu je prístup, ktorý maximalizuje geometrický priemer výnosov dost' zaujímavý a prít’ažlivý. 
Okrem dvoch vyššie spomenutých prístupov k optimalizácii portfólia, je potrebné uviest' d'alšie prístupy a odlišné predpoklady, konkrétne „kritérium bezpečnost' predovšetkým“" a „kritérium stochastickej dominancie“.

\section{* „Kritérium bezpečnost’ predovšetkým“}

Investori pri tvorbe portfólia musia uvažovat' aj s variantom, čo sa môže stat' v najhoršom prípade. Kritérium bezpečnost' predovšetkým sa zaoberá optimalizáciou portfólia za predpokladu, že investor sa zároveň snaží obmedzit' možnost' vzniku extrémne nízkych výnosov. V rámci tohto kritéria boli Royom, Kataokom a Telserom vyvinuté tri modely, ktoré sa navzájom do určitej miery odlišujú, ale ich spoločnou myšlienkou je obmedzenie možnosti vzniku extrémne nízkych výnosov.

Podl'a Royovho kritéria by si mal investor vopred stanovit' úroveň výnosu, pod ktorú sa nechce dostat' a následne minimalizovat' pravdepodobnost' dosiahnutia menšieho výnosu ako si stanovil.

Kataoka navrhuje, aby si investor určil prijatel'nú pravdepodobnost' neželaného výnosu a následne vybral to portfólio, ktoré má najvyšší očakávaný výnos pre danú pravdepodobnost'.

Telser rozčleňuje výber portfólia na dve procedúry, pričom investor by mal najprv splnit' podmienku, že pravdepodobnost' výnosu na konci obdobia, ktorý bude menší ako vopred stanovený výnos, bude menšia než určitá stanovená pravdepodobnost'. Následne z portfólií, ktoré spĺn̆ajú túto podmienku vyberie investor to portfólio, ktoré maximalizuje očakávaný výnos.

Z toho vyplýva, že výber portfólia na základe „kritéria bezpečnost' predovšetkým“ je vhodná pre riziko averzných investorov, ktorí chcú v prvom rade zamedzit' možnosti vzniku vel'mi nízkych výnosov.

\section{* „Kritérium stochastickej dominancie“6}

Táto metóda využíva len vel'mi všeobecne definované predpoklady, ktoré sú menej obmedzujúce v porovnaní s ostatnými metódami. Metóda stochastickej dominancie porovnáva varianty, na základe tvaru a vlastností ich distribučných funkcií. V závislosti od prijatých predpokladov možno rozlišovat' stochastickú dominanciu prvého, druhého a tretieho stupňa.

\section{Záver}

Porovnávané metódy optimalizácie portfólia možno zhrnút' nasledujúcim spôsobom. Ak je zámerom investora optimalizovat' portfólio pre jedno nasledujúce obdobie, vhodnou metódou je Markowitzov prístup k tvorbe portfólia. Ak chce investor naopak optimalizovat' svoje portfólio z dlhodobého hl'adiska, je presnejšie použit' kritérium maximalizácie geometrického priemeru výnosov. V prípade rizikovo averzného investora, ktorého prvoradým záujmom je ochrana pred vznikom extrémne nízkych výnosov, vhodnou možnost'ou sa javí kritérium bezpečnost' predovšetkým. Ak má investor záujem porovnat' 
niekol'ko variantov pri všeobecne definovaných predpokladoch, odporúčanou metódou je kritérium stochastickej dominancie.

\section{Literatúra}

[1] CHOVANCOVÁ, B. - JANKOVSKÁ, A. - KOTLEBOVÁ, J. - ŠTURC, B.: Finančný trh. Bratislava: Eurounion, 2002, ISBN 80-88984-31-9

[2] MARKOWITZ, H.: Portfolio Selection: Efficient Diversification of Investments. Edition. Oxford: Blackwell Publishing, 1991, ISBN 1-55786-108-0

[3] SHARPE, W. F. - ALEXANDER, G. J.: Investice, Praha, Victoria Publishing, 1994, ISBN 80-85605-47-3. 